\title{
Research on GE's Organization Innovation and Its Enlightenment
}

$$
\text { Pei-jin } \mathrm{LI}^{1} \text { and Liang TAN }{ }^{2, *}
$$

${ }^{1}$ School of Business English, Sichuan International Studies University, Chongqing 400031, China

${ }^{2}$ School of International Business, Sichuan International Studies University, Chongqing 400031, China

\section{${ }^{*}$ Corresponding author}

Keywords: GE, Organization innovation, Enlightenment.

\begin{abstract}
Joseph Schumpeter's innovation theory includes the following five categories: development of new products or improvement of original products; adoption of new methods of production; exploration of new markets; discovery of new ingredients or semi-manufactured goods; and creation of new industry organizations. In light of General Electric Company's case, this paper sums up five types of enterprise innovation capabilities in conformity with five categories in innovation theory, i.e., product innovation, technology innovation, market innovation, resource allocation innovation and organization innovation, with a detailed analysis on organization innovation and its enlightenment for Chinese enterprises.
\end{abstract}

\section{Innovation Theory}

\section{Definition of Innovation Theory}

The term innovation was first used by American economist Joseph Schumpeter in his book Theory of Economic Development published in 1912. Schumpeter holds that innovation is about establishing a new production function, namely, regrouping of essential production factors. Schumpeter classified innovation into five categories: a new product, a new production method, exploitation of a new sales market, discovery of new sources of supply for raw material or semi-finished products, and creation of a new industry organization. In reference to enterprise operation and management, the five options can be correspondingly understood as product innovation, technology innovation, market innovation, resource allocation innovation and organization innovation.

\section{Theoretical Expression of Innovation Theory}

The effects of innovation on output should be viewed in the following production function expressions. Suppose total production function takes the form of Cobb-Douglas, the total output level is the function of capital (K), labor (L) and technological level (A), the production function has the form shown here:

$$
\mathrm{Y}=\mathrm{F}(\mathrm{K}, \mathrm{L})=\mathrm{AK} \mathrm{L}^{\alpha-\alpha}
$$

The parameter $\alpha \in(0,1)$ here refers to the contribution proportion of capital to output in different countries or regions. Two scenarios are considered:

(1) Without technological advance:

$$
\mathrm{Y}=\mathrm{F}(\mathrm{K}, \mathrm{L})
$$

$$
\Delta \mathrm{Y}=(\mathrm{MPK} \times \Delta \mathrm{K})+(\mathrm{MP} \times \Delta \mathrm{L})
$$

The expression in the first brackets presents output increase arising from capital increase; while the latter shows output increase caused by labor increase. $M P K=F(K+1, L)-F(K, L)$ is the expression of marginal productivity of capital; while $\mathrm{MPL}=\mathrm{F}(\mathrm{K}, \mathrm{L}+1)-\mathrm{F}(\mathrm{K}, \mathrm{L})$ is marginal productivity of labor.

The formula (2) can be converted to: 
$\Delta \mathrm{Y} / \mathrm{Y}=[(\mathrm{MPK} \times \mathrm{K}) / \mathrm{Y}] \Delta \mathrm{K} / \mathrm{K}+[(\mathrm{MPL} \times \mathrm{L}) / \mathrm{Y}] \Delta \mathrm{L} / \mathrm{L}$

Assuming that the returns to scale do not change, (3) can be further converted into:

$$
\Delta \mathrm{Y} / \mathrm{Y}=\alpha(\Delta \mathrm{K} / \mathrm{K})+(1-\alpha)(\Delta \mathrm{L} / \mathrm{L})
$$

We can understand from formula (4) how the changes of capital and labor lead to the change of output.

(2) With technological advance

$$
\mathrm{Y}=\mathrm{AF}(\mathrm{K}, \mathrm{L})
$$

A represents the existing production technology, known as Total Factor Productivity, which was first proposed by American economist Robert Solo. Thus formula (5) can be changed accordingly based on formula (4):

$$
\Delta \mathrm{Y} / \mathrm{Y}=\alpha(\Delta \mathrm{K} / \mathrm{K})+(1-\alpha)(\Delta \mathrm{L} / \mathrm{L})+\Delta \mathrm{A} / \mathrm{A}
$$

(output growth) (capital contribution) (labor contribution) (TFP growth)

Total factor productivity can be calculated by the following equation:

$$
\Delta \mathrm{A} / \mathrm{A}=\Delta \mathrm{Y} / \mathrm{Y}-\alpha(\Delta \mathrm{K} / \mathrm{K})-(1-\alpha)(\Delta \mathrm{L} / \mathrm{L})
$$

Total factor productivity(TFP) refers to the ratio of total output to total factor input, and the growth rate of total factor productivity is often regarded as an indicator of technological progress. In the enterprise category, TFP is a conception based on product innovation, technology innovation, market innovation, resource allocation innovation and organization innovation. Below is an analysis on GE's organization innovation.

\section{Organization Innovation}

Organizational innovation means that the organization must constantly adjust and change organizational structure and management style along with the changing environment, through which organizations can adapt to environmental changes and achieve organizational goals.

Take the organization innovation by Immelt as an example, who succeeded Welch as the chairman and CEO of GE in 2001.

\section{Organizational Restructuring}

In 2003, Immelt integrated 25 business sectors which respectively belonged to long cycle, short cycle and financial services into 13 business groups, including eight industrial groups, four financial groups and one media group, the first organization innovation since his assumption of duty. The purpose is to further strengthen ties with customers, and strive for excellence in creating a world-class high-tech enterprise with customer orientation and effective use of the capital.

Table 1. 13 Major business groups of GE and their sales revenue in 2002

\begin{tabular}{cll}
\hline$\#$ & \multicolumn{1}{c}{ Group Name } & \multicolumn{1}{c}{ Performance in 2002} \\
\hline 1 & General Electric Aircraft Engines & Sales Revenue: $\$ 11.1$ billion \\
2 & Consumer Product Group & Sales Revenue: $\$ 8.5$ billion \\
3 & Industrial Systems Group & Sales Revenue: $\$ 5$ billion \\
4 & Healthcare System Group & Sales Revenue: $\$ 9$ billion \\
5 & Plastics Group & Sales Revenue: $\$ 5.2$ billion \\
6 & Power System Group & Sales Revenue: $\$ 22.9$ billion \\
7 & Special Materials Group & Sales Revenue: $\$ 2.4$ billion \\
8 & Transportation System Group & Sales Revenue: $\$ 2.3$ billion \\
9 & Commercial Finance Group & Total Assets: $\$ 195.8$ billion \\
10 & Consumer Financial Services Group & Total Assets: $\$ 77$ billion \\
11 & Equipment Management Group & Total Assets: $\$ 26.1$ billion \\
12 & Insurance Group & Total Assets: $\$ 182.3$ billion \\
13 & National Broadcasting Company & Sales Revenue: $\$ 7.1$ billion \\
\hline
\end{tabular}

In 2004, Immelt performed another restructuring concentrating on markets and customers and reorganized 13 business groups to 11 . The new structure includes seven growth engines and four 
cash generators. As the market leaders possessing influential strengths in technology, cost, service, global distributions and capital efficiency, the following engines are all star businesses: Consumer Financial Services Group, Commercial Finance Group, Energy Group, Healthcare Group, Infrastructure Group, Transportation Group, and National Broadcasting Company, all of which produce $85 \%$ of total profits. The four cash generators, Advanced Materials Group, GE Consumer \& Industrial, Equipment Service Group and Insurance Group, are classified as "cash cow" businesses which can continuously produce annual cash flow and profits in growing economic environment.

Based on the seven growth engines, GE added more than a dozen new growth-oriented businesses: life sciences, DVD films, medical information technology, renewable energy, coal gasification, water treatment, security, Spanish language TV, oil and gas exploration technology, financing for various industries, financing for supply chains, real estate, global mortgage loans, etc, revealing GE's foothold on the present and outlook for the future.

Immelt's third business integration came in 2005. Eleven business groups of GE were merged into six groups, namely three industrial groups: infrastructure, healthcare, and industry; two financial groups: business finance and consumer finance; and NBC Universal.

Table 2. GE's six major business groups (2005)

\begin{tabular}{|c|c|c|c|c|c|}
\hline Infrastructure & Industrial & Healthcare & $\begin{array}{c}\text { Commercial } \\
\text { Financial Services }\end{array}$ & $\begin{array}{c}\text { Consumer } \\
\text { Finance }\end{array}$ & $\begin{array}{c}\text { NBC } \\
\text { Universal }\end{array}$ \\
\hline Oil \& Gas & $\begin{array}{c}\text { Strategy } \\
\text { Integration }\end{array}$ & $\begin{array}{c}\text { Diagnostic } \\
\text { Imaging }\end{array}$ & Insurance & Europe & Network \\
\hline Energy & $\begin{array}{c}\text { Consumer \& } \\
\text { Industrial }\end{array}$ & $\begin{array}{c}\text { Clinical } \\
\text { Systems }\end{array}$ & Leasing & Asia & Stations \\
\hline Rail & Equipment Svcs & $\begin{array}{c}\text { Info } \\
\text { Technology }\end{array}$ & Real Estate & Americas & Entertainment \\
\hline Aircraft Engines & Plastics & Services & $\begin{array}{c}\text { Corporate Fin } \\
\text { Svcs }\end{array}$ & $\begin{array}{c}\text { Australia/New } \\
\text { Zealand }\end{array}$ & Universal \\
\hline water & $\begin{array}{c}\text { Silicones } \\
\text { Quartz }\end{array}$ & Bio Sciences & $\begin{array}{c}\text { Healthcare Fin } \\
\text { Svcs }\end{array}$ & $\begin{array}{c}\text { Sports/ } \\
\text { Olympics }\end{array}$ \\
\hline Energy Fin Svcs & Security & & & & \\
\hline Aviation Fin Svcs & Sensing & & & & \\
\hline
\end{tabular}

The economic background of the three major adjustments is the recession caused by 911 event in the United States, which led to a continuous contraction and optimization of GE's organizational structure. The big adjustments were followed by small ones. In September 2006, GE signed an agreement with the U.S. Apollo Investment Corp on the sales business of silicone and quartz of GE Hi-tech Group, the transaction cost amounted to 3.8 billion dollars. In May 2007, GE sold its plastics business for $\$ 11.6$ billion to Saudi Arabia Basic Industries Corporation, SABIC for short, the largest industrial company in Saudi Arabia, facilitating GE's further transfer to high-growth and high-return areas coupled with selling the Hi-tech Material Group ${ }^{1 .}$

\section{People Development}

Organization innovation means not only constantly adjusting organizations with the changing environment, what matters more is to combine the development of personnel with organizational goals, through which individuals can actively adapt to environmental changes so as to achieve organizational goals. In fact, GE has its own unique mechanism in talent cultivation and development.

This unique mechanism is marked by Crotonville School of Management, a training center for GE's senior management personnel founded in 1954, which covers an area of 58 acres, and is located by the Hudson River, New York. It was referred to as the cradle of the growth of GE senior cadres by some people and Harvard in American business world by Fortune magazine. As many as 173 among Fortune 500 CEOs received training in Croton School of Management, which lives up to its reputation of a factory fostering CEOs. 
After Welch took office, he invested $\$ 45$ million to expand the scale of the school. Croton School of Management is not only the first management school established by an enterprise, but also the most prestigious school of business management in the world. GE led the change through the training of leaders.

The mission of the School is to create, determine and spread knowledge of corporation to grease the wheels of GE and improve its competitive strengths in the world. Specifically, the School's tasks are providing training for the growth and development of GE employees, sharing best practice, company initiatives and learning experience among business sectors, and transmitting company culture and values.

The number of GE senior managers receiving training in Croton School of Management amounts to 5,000 annually who come from GE's various business sectors in the world, and half of the faculty are senior executives of GE, Welch, the former chairman and CEO of GE, and Immelt, current chairman and CEO are included. During Welch's tenure, he was seen more than 250 times in the classroom, teaching in person the managers and administrators with a total number of about 18,000, revealing his significant emphasis on training programs.

The training process starts from new employees. On-boarding training can help them understand GE's business contents, corporate culture and values, performance evaluation standard, management system, and so on. One of its important contents is to get new employees understand GE's culture and values, which is the key to their development and growth in GE, and the core aspect of value is integrity, thus the training about abiding by laws and regulations is also involved.

On-boarding training is followed by omnifarious skill training and leadership training. Skill training include Six Sigma Green Belt, Six Sigma Black Belt, Six Sigma Master Black Belt, team work, change the acceleration process, presentation skills, marketing skills, and so on. In general, the employees are required to participate in at least two skill training programmes each year, so almost all reasonable applications from staffs will be approved by managers. Leadership training should be a necessity for those who want to achieve a breakthrough in career development and of course it involves their line managers' recommendation. Table 5 is a demonstration of GE's training system.

Table 3. GE's training system

\begin{tabular}{|c|c|c|}
\hline \multirow{2}{*}{ Presidential Level } & SVP & Executive Development Course, EDC \\
\hline & VP & Business Management Course, BMC \\
\hline \multirow{2}{*}{ Executive Level } & SEB & \multirow{2}{*}{ Manager Development Course, MDC } \\
\hline & EB & \\
\hline \multirow{3}{*}{ Technical Level } & SPB & \multirow{2}{*}{ New Manager Development Course, NMDC } \\
\hline & LPB & \\
\hline & PB & Foundations of GE Leadership \\
\hline
\end{tabular}

The growth of GE's leading personnel all experienced three phases without exception. The first stage is the first five years since their entry into the corporation. They need to be very familiar with their own areas of expertise and achieve success in relative jobs. They participate in this phase the training programs about GE leadership fundamentals or development course for new managers, while at the same time implementing challenging tasks, from which the leadership ability can be developed and confidence can be enhanced. The second stage is when they have worked for five to fifteen years since their entry, during which they have already assumed responsibility for team management and have participated in various businesses, creating opportunities for them to meet senior leaders, and to have face-to-face communication with them. Development courses for managers is the focus of company training in this stage targeting to help them become really excellent managers. The third stage starts when they have worked for at least fifteen years during which they have become the decision makers of sectors and shoulder full responsibility, which means there's no one to blame other than himself if any task has not been completed. What's more, they have possessed extensive interpersonal networks. In other words, they own not only leadership ability but also an extension of interpersonal networks. Therefore, the emphasis of the training courses at this stage is laid on business management and development courses for senior 
management personnel, which are required courses for GE's senior leaders. All training courses are held in the center of Crotonville School of Management in New York, and each session lasts three and a half weeks.

Since its foundation in 1892, GE has experienced one hundred and twenty years of development owing to its continuous innovation. Under the leadership of twelve leaders throughout one hundred and twenty years, GE evolved from a small professional electric company with no more than tens of millions of dollars annual sales revenue to the only diversified world-class corporation which has been ranking among the top ten of the Global 500 firms for years. GE is also the only corporation which is still on the index list of the company since the establishment of Dow Jones industrial index in 1896. The development process lasting more than one hundred years is at the same time the formation process of GE's innovation capabilities, which are labelled as one of the core competitive strengths of GE.

\section{Enlightenment from GE's Organization Innovation}

Organizational Innovation implies two levels of meanings: one is constant adjustment of organization with the changing environment; and the other is the combination of human growth with organizational goals.

On the first level, only a few domestic enterprises can take the initiative to adjust organization structure with changing environment, most enterprises tend to do it passively when they are faced with operation dilemma and financial distress, which inevitably brought nothing but loss of many market opportunities. Whereas, it is people themselves who can grasp opportunities and the cultivation of talents becomes a pressing issue to be solved.

Then the second level is about talent cultivation. The path we are following is learning from the development of GE. As early as 1985 when Welch visited China, an agreement titled China -GE management training program was signed between GE and Chinese government, providing training opportunities for Chinese senior management personnel. In 1986, having received English language training, the first batch of senior management training class designated by the State Economic Commission was sent from Beijing to New York. A majority of the trainees are college-educated factory directors or managers of large enterprises. They got trained for a month first in Croton Institute of Management, and the curriculum there was basically a condensed version of MBA curriculum. Then they were arranged to make in-depth company visits to investigate and study practical experience. "China -GE management training program" has been held once a year since 1993.

When Premier Zhu Rongji visited the United States in 1999, he met with Welch after the meeting with President Clinton. Premier Zhu said, "As China is in great need of senior management talents and GE is world-famous for excellent management so I wonder if your company can help Chinese enterprises in this regard?" In the same year, Welch, on behalf of the CEOs of Fortune 500 companies, made a finale speech in Fortune Forum held in Shanghai. Welch was sitting next to President Jiang Zemin during reception dinner, and the training issues about Chinese senior management seminar were finally settled. The participants of the seminar were either officials on provincial level or chairmen or general managers of Chinese enterprises. The seminar has been held more than ten sessions since 2000 resulting in over 200 graduated trainees.

Since then, more and more CEOs or senior managers from other domestic enterprises rushed to sign up classes of MBA or EMBA training courses with GE, laying a good foundation for the following transformation of enterprises. In addition, some large Chinese enterprises have combined talent development with organizational goals, and proposed the slogan of promoting those possessing both integrity and professional competence; cultivating those possessing integrity but lack competence; use with caution those possessing competence but lack integrity; and abandoning those without integrity and competence. In this case, the organization innovation of domestic enterprises is definitely worth our expectation. 


\section{References}

[1] Joseph Schumpeter, Introduction to Economic Development, The Commercial Press, 2000.

[2] http://www.ge.com

[3] Liang TAN, Chuan-zhao LI, A probe into electric enterprises' competitiveness and R\&D investment from microcosmic perspective: based on extended CES model application of the Top Hundred Corporations, Soft Science. 7 (2010) 37-42. 